\title{
CONVERSÃO E RECONVERSÃO DE PADRES NO MARANHÃO'
}

\section{CONVERSION AND RECONVERSION OFF PRIEST IN MARANHÃO}

Wheriston Silva Neris*

\section{Introdução}

Em La vocation: conversion et reconversion des prêtres ruraux (1978), Charles Suaud analisou a situação da província de Vendée (diocese de Luçon) como uma área privilegiada para o estudo das transformações ocorridas na formação de habitus profissionais e religiosos, correlativamente às reconversões econômicas ocorridas nessa área, a partir da década de 1960. Para isso, Suaud se dedicou tanto à compreensão dos condicionantes sociais e institucionais da conversão religiosa, ou seja, os determinantes que permitiriam explicar o surgimento da vocação sacerdotal como um fenômeno social e suscetível de expli- cação, quanto dos fatores que explicariam a reconversão dos padres rurais face à crise brutal de vocações ocorrida nesse marco temporal. No cerne do trabalho encontrase a perspectiva de que essa crise resultaria da própria transformação das estratégias de reprodução dos grupos rurais e, em particular, da expansão das oportunidades de escolarização e destinos profissionais, o que teria incidido sobre a atratividade, a função e o estatuto ocupado pelo sacerdote dentro da comunidade rural.

Focalizando as mutações no processo de aquisição da competência religiosa, Charles Suaud (1978) distinguiu então a existência de três gerações sacerdotais: os padres tradicionalistas; os sacerdotes preparados

\footnotetext{
* Doutor em Sociologia pela Universidade Federal de Sergipe. Professor do Colegiado de Ciências Humanas da Universidade Federal do Maranhão - Campus III (Bacabal/MA/BR). wheristoneris@yahoo.com.br. 1. Uma versão inicial deste trabalho foi apresentada no Grupo de Trabalho "Elites e espaços de poder" do 39 Encontro Anual da Associação Nacional de Pós-Graduação e Pesquisa em Ciências Sociais (ANPOCS) em outubro de 2015. Esta versão beneficiou-se das críticas e comentários realizados na ocasião e também das argutas sugestões dos pareceristas da REPOCS, pelo que sou grato.
} 
para a crise e a geração dos padres da nova Igreja. A primeira categoria abrangia os sacerdotes com mais de 50 anos, inadaptados às novas condições de exercício do papel religioso e praticamente impermeáveis às transformações em curso. A segunda geração, por outro lado, socializada entre os anos 1960-1965, incluía os agentes religiosos formados em um momento de relativização das formas instituídas e cujos $h a-$ bitus seriam caracterizados pela disposição ao duplo-jogo, ou seja, ao mesmo tempo em que saberiam agir para transformar a instituição quando possível, esses agentes poderiam autocensurar-se quando considerassem necessário. A terceira geração, formada entre 1965-1970, englobaria os agentes que se consideravam porta-vozes de uma renovação necessária do campo eclesial, assumindo um combate aberto contra todos aqueles que nesse espaço defendiam concepções conservadoras sobre a Igreja e os papéis sacerdotais (a este respeito, ver também: RAISON DU CLEZIOU, 2011). Para Suaud (1978), em suma, se o aggiornamento católico recebeu a adesão de uma parcela específica do clero, essa "recepção" só foi possível devido às transformações na formação sacerdotal e ao processo mesmo de diversificação dos habitus religiosos. Nesse sentido, como também o observou Yann Raison du Cleziou (2011), a produção de habitus sacerdotais, diferenciados das gerações anteriores, era precisamente o que habilitava aos padres socializados no novo modelo a perceberem as recentes propostas teológicas e as inovações sacerdotais da Igreja pós-conciliar como relevantes.

Com essa inspiração de fundo, a investigação que está na base deste artigo teve como preocupação central examinar as mediações concretas por meio das quais certos membros do corpo clerical foram conduzi- dos a viver sua atividade profissional como diretamente política e socialmente engajada, tendo como referencial de análise um espaço empírico representado pelo Maranhão, a partir da segunda metade do século XX (NERIS, 2014b). Com base em procedimentos metodológicos variados, o estudo buscou então compreender como a instituição eclesiástica se tornou um lugar de politização de indivíduos, por meio da objetivação das formas e mecanismos que suscitaram o trânsito de lógicas entre esferas de atividade, promovidos por determinados agentes que desafiaram as definições e os limites legitimados da ação religiosa católica. Por essa via, ainda, ao escolher como objeto de estudo um componente institucional periférico, pretendíamos reconstituir as modalidades concretas e contingentes de transação entre os fenômenos religiosos e políticos, atentando para as configurações históricas, sociais e institucionais particulares e, inclusive, para os discursos produzidos por um pequeno número de indivíduos que explorou novas vias de definição do papel sacerdotal. A estratégia metodológica adotada incluía desde a realização de entrevistas biográficas com religiosos reconhecidos pelo seu engajamento passado em causas sociais na região, até o recurso a uma rede articulada de materiais empíricos, tais como: publicações de caráter historiográfico, fontes documentais da instituição (correspondências, livros de registro, relatórios), jornais de circulação regional, produções de teor biográfico e memorialístico, bem como dados estatísticos variados (IBGE, Anuários Católicos).

Com efeito, a tentativa de tornar inteligível como esses religiosos foram conduzidos a transgredir os limites legítimos da ação religiosa tem nos conduzido, desde então, a identificar diferentes matrizes do 
processo de politização religiosa. Assim, se já tivemos a oportunidade de sublinhar em trabalhos recentes o quanto essas recomposições das formas de exercício religioso na igreja maranhense se associam às reconfigurações do internacionalismo católico e às experiências de deslocamento de clérigos em situação de missão no exterior - por exemplo, ao analisar gerações de sacerdotes vinculados a dioceses estrangeiras, os chamados padres Fidei Donum (NERIS; SEIDL, 2015b; 2015c), ou mesmo a evolução da perspectiva religiosa em um instituto de origem italiana, os Missionários Combonianos do Coração de Jesus (MCCJ) (NERIS; SEIDL, 2015a) -, neste texto pretendo discutir a sociogênese da politização do engajamento religioso, com atenção às modificações nas condições de possibilidade e realização de reconversões militantes de clérigos diocesanos ${ }^{2}$ de origem local, que escolheram uma definição do ofício como socialmente engajada no Maranhão contemporâneo.

A dinâmica entre conversão e reconversão de padres, claramente inspirada no trabalho de Charles Suaud (1978), designa aqui justamente esse processo de incorporação e contraincorporação de disposições sacerdotais que envolve sempre um alongado trabalho de reconstrução de si (SUAUD, 1991). Por essa razão, como também esclarece Sylvie Tissot (2005), embora essas reconversões possam ser concebidas em termos de histórias edificantes, formas de (re)encantamento ou até mesmo como ascensões fulgurantes, elas podem dar lugar também a experiências inconstantes, ambíguas, dolorosas e/ou problemáticas. Desse ângulo, o exame contextualizado e contextualizante das condições de possibilidade de transformação de disposições adquiridas anteriormente constituiu eixo importante neste trabalho para captar a dinâmica complexa de confluência entre percursos individuais e as próprias recomposições do espaço religioso no recorte em pauta. Trata-se da concepção de que, se certos contextos políticos e organizacionais favorecem esse processo de redefinição, há que se levar em conta também que as reconversões geralmente englobam deslocamentos no espaço social, supondo ainda um trabalho discursivo de justifıcação e de redefınição de si (TISSOT, 2005).

Tendo em vista essas diferentes dimensões, neste texto examina-se o processo de dupla conversão de padres maranhenses a partir de três dimensões interconectadas. Em primeiro lugar, examinamos as mutações na composição social do clero atuante na região até o último quartel do século XX, tentando demarcar as condições de crise de recrutamento sacerdotal. Em seguida, exploramos os efeitos da emergência de novas demandas religiosas, resultantes dos investimentos institucionais em direção a novos públicos, sobre as modalidades legítimas de exercício do papel religioso. Por fim, através da exploração da narrativa biográfica de uma trajetória sacerdotal, pretende-se demarcar não somente as condições inseparavelmente individuais e coletivas de requalificação das atividades religiosas, como também aprofundar a compreensão sobre um processo de reconversão religiosa realizada em seu "sentido forte", como bem esclarece Monique de Saint-Martin, a saber: como "uma forma de

2. Cabe esclarecer que o clero secular (também conhecido como diocesano) é composto pelo conjunto de sacerdotes vinculados a uma Igreja particular, ou seja, a uma figura jurídica em torno de um bispo (Arquidiocese, diocese, administração apostólica, prelazia territorial, pessoal etc.). 
ruptura com a herança, uma dissolução dos antigos recursos e uma recomposição destes recursos em bases diferentes, bem como uma reconstrução identitária" (SAINT-MARTIN, 2008, p. 65).

\section{A seleção e recrutamento dos efetivos clericais no Maranhão}

Acompanhando as transformações na composição social do clero diocesano atuante no Maranhão desde os primórdios do século XX, o que se nota é o aprofundamento do vínculo do sistema de recrutamento católico com o universo rural ${ }^{3}$. Na realidade, essa tendência já era anterior, como pudemos constatar em outra pesquisa a respeito da elite eclesiástica regional na segunda metade do século XIX (NERIS, 2014a). Nesse período, como concluiamos, paralelamente a uma diminuição do peso dos recrutados entre as "grandes famílias", assistiu-se a um incremento na representação daqueles "alunos brilhantes" vindos de pequenas comuni- dades de zonas rurais relativamente pobres do interior, ou mesmo de ofícios dos grupos dominados, cujo acesso à carreira eclesial significava uma possibilidade de ascensão social. Posteriormente, do início do período republicano até a década de 1960, essa tendência se manteve contínua entre os 78 clérigos diocesanos maranhense ordenados ao longo de oito sucessões episcopais na Arquidiocese do Maranhão, dentro do recorte em pauta. Além disso, embora levemos em consideração que os três primeiros bispados ainda se ressentiam dos efeitos da crise de vocações de finais do século XIX (entre 1901 e 1918 foram ordenados apenas quatro sacerdotes), o fato é que a curva dos efetivos sacerdotais não cessou de aumentar entre 1918 e 1944, quando ocorreu o período de maior produção de vocações sacerdotais na região. A partir de 1945, no entanto, observa-se um decréscimo nos índices de ordenação, alcançando o seu ponto mais crítico nas décadas de 1960-1970. 
Quadro I - Ordenações sacerdotais x sucessões episcopais na Arquidiocese maranhense.

\begin{tabular}{|c|c|c|}
\hline Dom Xisto Albano & 1901-1905 & 1 ordenado: Padre Gregorio Luiz de Barros. \\
\hline $\begin{array}{l}\text { Dom Santino Maria } \\
\text { da Silva Coutinho }\end{array}$ & 1906 & Transferido para Belém antes da sagração \\
\hline $\begin{array}{l}\text { Dom Francisco de } \\
\text { Paula e Silva }\end{array}$ & $1907-1918$ & $\begin{array}{l}3 \text { sacerdotes: Gentil de Moura Viana; Felipe Benício Condurú } \\
\text { Pacheco; Pe. Arias Almeida Cruz. }\end{array}$ \\
\hline $\begin{array}{l}\text { Dom Helvécio Gomes } \\
\text { de Oliveira }\end{array}$ & 1918-1922 & $\begin{array}{l}8 \text { ordenações: João Possidonio da Senna Monteiro; José Poly- } \\
\text { carpo Seabra Ayres; Newton de Carvalho Neves; Raimundo Raul } \\
\text { Ramos; Eliud Nunes Arouche; Raimundo Romualdo Martins; } \\
\text { José Alexandre Pereira da Silveira; Eurico de Freitas Silva. }\end{array}$ \\
\hline $\begin{array}{l}\text { Dom Otaviano Pereira } \\
\text { de Albuquerque }\end{array}$ & $1922-1935$ & $\begin{array}{l}26 \text { ordenados (23 maranhenses): João Severo Ramos de Oli- } \\
\text { veira; Odorico Braga Nogueira; Nestor de Carvalho Cunha; } \\
\text { Eurico Pinheiro Bógea; Gilberto de Almeida Barbosa; Luiz } \\
\text { Gonzaga Monteiro da Silva; Antonio Edson Lobão Nolêto; } \\
\text { Constantino Trancoso Vieira; Astholpho de Barros Serra; Os- } \\
\text { mar Palhano de Jesus; Joaquim de Jesus Dourado; José de Ri- } \\
\text { bamar Montelo Rapôso; Newton Ignácio Pereira; Manoel Nu- } \\
\text { nes Arouche; Carlos do Bonfım Couto Bacelar; Benedito Co- } \\
\text { elho Estrela; Clovis Vidigal; Alfredo Furtado Bacellar Filho; } \\
\text { Cincinato Ribeiro Rêgo; Delfıno da Silva Júnior, Artur Lo- } \\
\text { pes Gonçalves; Gerson Nunes Freire; Joel Barbosa Ribeiro; Jo- } \\
\text { sé Xavier de Almeida Júnior; Raimundo de Amorim Carvalho; } \\
\text { Frederico Pires Chaves. }\end{array}$ \\
\hline $\begin{array}{l}\text { Dom Carlos Carmelo } \\
\text { de Vasconcelos Mota }\end{array}$ & $1935-1944$ & $\begin{array}{l}12 \text { Ordenados: Padres René Carvalho; Pedro Rodrigues da } \\
\text { Cunha Santos; Fernando de Albuquerque Vasconcelos; Luis } \\
\text { Mota; José Wigh; Jocy Neves Rodrigues; Ladislau Papp; Pau- } \\
\text { lo Monteiro Sampaio; Clodomir Brandt e Silva; João Batista } \\
\text { Costa; Alteredo Soeiro Mesquita; José de Freitas Costa. }\end{array}$ \\
\hline Vacância & $1945-1946$ & $\begin{array}{l}3 \text { ordenados no período de vacância: Francisco Dourado e Sil- } \\
\text { va; Julio de Freitas Costa; Valter de Castro Abreu }\end{array}$ \\
\hline $\begin{array}{l}\text { Dom Adalberto Ac- } \\
\text { cioli Sobral }\end{array}$ & $1947-1951$ & $\begin{array}{l}6 \text { ordenações: José Albino Campos; José de Ribamar Car- } \\
\text { valho; Benedito Ewerton Costa; Eider Furtado da Silva. Em } \\
\text { Caxias foram ordenados dois presbiteros: Leonel Carvalho; } \\
\text { Oton Salazar. }\end{array}$ \\
\hline $\begin{array}{l}\text { Dom José de Medeiros } \\
\text { Delgado }\end{array}$ & 1951-1963 & $\begin{array}{l}13 \text { ordenações: José de Jesus Travassos Furtado; Wilson Nu- } \\
\text { nes Cordeiro; Benedito Chaves de Lima; Manuel Prestes de Li- } \\
\text { ma; Cicero de Jesus Silva; Helio Maranhão; Sidney Castelo } \\
\text { Branco Furtado; Manoel de Jesus Soares; João Miguel Moha- } \\
\text { na; Luis Mario Lula; Francisco Soares de Sousa; Heitor Pieda- } \\
\text { de Filho; Flávio de Sousa Barros }\end{array}$ \\
\hline
\end{tabular}

Fontes: PACHECO (1969) e Livro de Registro do Clero no Maranhão 
Esse aumento na curva dos recrutamentos poderia ser atribuído pelo menos a dois fatores fundamentais, que vale a pena explorar brevemente. Em primeiro lugar, a reabertura e reestruturação do Seminário Diocesano de Santo Antônio (1904), localizado na cidade de São Luís do Maranhão e sob a direção da Congregação da Missão (Lazaristas ou Vicentinos) - família religiosa vinda para a região a convite de Dom Antônio Xisto Albano (1901-1906). Segundo, pelo papel desempenhado pela "Obra de Vocações Sacerdotais” ou “Associação de São José” para o financiamento de vocações entre as camadas populares e locais.

Quanto ao papel desempenhado pelo Seminário Diocesano Santo Antônio, quando se passa à análise da importância dessa instituição no sistema de reprodução do corpo clerical no Maranhão, o primeiro aspecto que se ressalta nos itinerários desses sacerdotes diocesanos é a forte ligação entre a formação promovida pelo Seminário e a opção pela carreira eclesiástica. Após uma breve passagem pelas escolas primárias de povoados e paróquias do interior, independentemente de suas origens sociais, os estudos da quase totalidade desses clérigos se resumiram à formação que recebiam no seminário diocesano regional, localizado na capital do estado do Maranhão. A partir do ingresso, esses jovens deviam submeter-se então a um rígido treinamento “tridentino" para apropriação dos valores, normas e condutas institucionais: distanciamento progressivo do núcleo familiar; longo período de formação; horários rígidos e severidade disciplinar; realização de numerosas disciplinas clássicas; orientação filosófica com base na tradição aristotélicotomista etc. (MICELI, 1988; SERBIN, 2008). Tratava-se aqui de um modelo de (re)so- cialização fortemente padronizado, com ênfase no preparo intelectual, cuja função seria promover um sentimento de pertencimento subjetivo à instituição. Tudo isso que se mostraria necessário para formar uma comunidade religiosa homogênea, distinta e unificada, contribuindo ainda para a formação de um contingente de padres leais à autoridade episcopal, e sintonizados com as pretensões de poder e influência da Igreja nos primórdios do período republicano (BEOZZO, 1986; MICELI, 1988; NERIS, 2014b; RIBEIRO, 2003).

Embora a representação do métier sacerdotal assumisse feições cada vez mais eruditas e elitistas com a estruturação do seminário regional, o recrutamento sacerdotal continuou, como dito, a concentrar-se gradativamente sobre os segmentos sociais mais desprovidos de recursos econômicos e culturais. É o que se pode notar quando se analisa a importância assumida pela Obra de Vocações Sacerdotais (doravante, OVS) para a produção de vocações locais. A OVS consistiu em organismo criado no início do século XX (1906) para angariar fundos para a formação de sacerdotes pobres, que não dispunham de recursos suficientes para custear seus estudos secundários e superiores até a formação sacerdotal. Idealizado por um lazarista francês, de uma associação dotada de parcos recursos e meramente auxiliar na produção de vocações que, a princípio, conseguiu afirmar-se como principal fundo de financiamento sacerdotal na região em pouco mais de uma década. $\mathrm{Na}$ realidade, o impacto dessa associação foi até bem mais amplo e difuso, se levarmos em conta que nem todos os estudantes que tiveram seus estudos pagos pela associação chegaram a investir na carreira sacerdotal. Essa Obra funcionou até a década de 1960 (RIBEIRO, 2003; PACHECO, 1969) 
Os relatórios da OVS, descritos por Condurú Pacheco (1969), podem ser utilizados para explicitar a importância dessa agremiação. À frente dessa associação alternaramse padres lazaristas e sacerdotes diocesanos locais. Os primeiros relatórios davam conta do aumento do número de seminaristas, elevando-se de 8 em 1907, para 20 em 1913 e 21 em 1918, entre 72 seminaristas inscritos. Vinte anos depois, em 1937, a Obra já havia ordenado mais de 21 sacerdotes e mantinha outros 21. Em 1940, com a elevação do número de associados e as solicitações contínuas de bispos e sacerdotes para o empenho dos fiéis na produção de recursos para a Obra, os relatórios já apontavam que 40 alunos eram pagos pela Associação São José e outros 14 recebiam meia pensão. Devido à OVS, em pouco mais de três décadas de criação, o percentual de sacerdotes havia se elevado notavelmente, em comparação com os primeiros decênios do século XX.

Com a Obra de Vocações Sacerdotais, os seminários diocesanos puderam então recrutar majoritariamente o clero diocesano no universo das camadas populares e modestas rurais. Ilustrativo disso, para o período de 1945 a 1963, levando em consideração as 22 ordenações de que temos notícia, 17 vinham de localidades no interior do estado. Porém, um relatório de 1962 mostrava que essa tendência de crescimento já apresentava sinais de desgaste. Em uma das passagens desse plano de evangelização, pode-se encontrar a seguinte avaliação:

A classe média e a classe rica (pouco numerosa) quase não dão candidatos ao sacerdó- cio. A pobreza e a deficiência econômica da maioria dos candidatos obrigam a OVS a esgotar seus recursos na manutenção do Seminário e não permitem melhorar as condições de instalação do edifício e do seu adequado equipamento (DELGADO, 1962).

Já na década de 1960, esse declínio atingiu o seu pico de intensidade colocando problemas para a realização das tarefas, as mais rotineiras, e exigindo dos representantes institucionais esforços crescentes, na proporção em que a situação se deteriorava. Entre as poucas fontes compulsadas que davam informações sobre os seminaristas, o Anuário Estatístico do Brasil de 1952 (IBGE, 1952) mencionava, por seu turno, que em todo o Maranhão havia somente 55 inscritos em seminários menores, e 16 no maior ${ }^{4}$. Em outro relatório sobre a situação do recrutamento sacerdotal no Maranhão, Dom José de Medeiros Delgado (1951-1963) indicava que apesar dos investimentos para solucionar a escassez de vocações, os seminários terminaram sendo simples colégios paroquiais, atraindo cada vez menos alunos.

Entre 1952 e 1962, matricularam-se 256 seminaristas no Seminário de Santo Antônio, sendo deste 32 no Seminário maior. Ordenaram-se nestes 10 anos, 14 padres, 12 dos quais mantidos total ou parcialmente pela Associação de São José. De grande auxílio foi para o seminário a Procuradoria da Messe, que reorganizei em 1952. Por deficiência de alunos, foi fechado o Seminário Maior em 1953, quando foram transferidos os alunos de teologia e filosofia para outros seminários

4. Vale mencionar que esse quadro se contrastava fortemente com o caso do Seminário de Viamão, no Rio grande do Sul, que nessa mesma época se tornava o maior celeiro de vocações na América Latina (SEIDL, 2003). 
e reabriu em 1962 com o curso de filosofia (5 anos). Entre 1952 e 1962, observa-se um índice decrescente de perseverança, criando-se um hiatus de 6 anos sem nenhuma ordenação sacerdotal (PACHECO, 1969, p. 777).

Entre 1960 e 1963, conforme Condurú Pacheco (1969, p. 777), o número de alunos matriculados no seminário de Santo Antônio foi reduzido de 68 para 20, “[...] dos quais apenas 2 cursam filosofia no seu $3^{\circ}$ ano". Com a saída dos Lazaristas da direção dessa instituição, em 1963, em pouco tempo o seminário fechou suas portas, praticamente sem alunos, e suas dependências passaram a ser alugadas para a realização de eventos, congressos e simpósios, com o que a Cúria obtinha uma fonte de renda auxiliar (MEIRELLES, 1977). Levando-se em conta os decênios de 1960 a 1980, embora as estatísticas não estejam padronizadas ${ }^{5}$, principalmente para os dois primeiros períodos (1963-1968; 1970-1976), conforme o quadro abaixo, é possível notar a timidez da evolução dos efetivos presbiterais diocesanos. Se entre 1963 e 1968 o número de sacerdotes diocesanos (incluindo nacionais e estrangeiros) atuantes no Maranhão era de aproximadamente 99, esses efetivos foram reduzidos ainda mais entre 1970-1976 (NERIS; SEIDL, 2015c). É nesse sentido, inclusive, que se podem melhor compreender as iniciativas encabeçadas por prelados de dioceses maranhenses que desde a década de $1950^{6}$ se dirigiram, a título pessoal, a diversos episcopados (Canadá, Estados Unidos, França, Bélgica, Espanha) e a congregações religiosas de outros países para enviarem religiosos ao Maranhão, o que contribuiu para aprofundar a dependência de clérigos estrangeiros, fossem eles regulares ou diocesanos (NERIS, 2014b).

5. Uma vez que não dispusemos de dados precisos sobre a evolução das ordenações entre 1960-1980, entre os fundos estatísticos examinados, talvez os dados produzidos pelo Anuário Pontifício e sistematizados em diversos sites da internet constituam as melhores fontes de informação sobre a evolução numérica dos contingentes clericais em nível regional. Com efeito, além da informação sobre os clérigos atuando na estrutura diocesana (fossem eles sacerdotes ou regulares), eles apresentam informações sobre a população, os batizados, paróquias e números de religiosos masculinos e femininos.

6. Para o caso da arquidiocese, consultar Meirelles (1977). Em relação às dioceses de Pinheiro e Viana, consultar Neris (2014b). 
Quadro II - Sacerdotes diocesanos no Maranhão

\begin{tabular}{|c|c|c|c|c|}
\hline Circunscrição Eclesiástica & 1963-1968 & 1970-1976 & 1980 & 1989 \\
\hline Arquidiocese de São Luís & $1965-51$ & $1976-17$ & 21 & 18 \\
\hline Grajaú & - & $1976-2$ & 18 & 6 \\
\hline Caxias & $1967-13$ & $1974-11$ & 11 & 13 \\
\hline Pinheiro & $1966-20$ & $\begin{array}{l}1970-17 \\
1976-17\end{array}$ & 14 & 15 \\
\hline Balsas & - & - & 2 & 5 \\
\hline Carolina & - & - & 4 & 4 \\
\hline Candido Mendes/Ze Doca & $1968-6$ & $1976-6$ & 8 & 6 \\
\hline Viana & $\begin{array}{l}1965-7 \\
1968-9\end{array}$ & $1976-7$ & 3 & 10 \\
\hline Bacabal & - & $\begin{array}{l}1970-2 \\
1976-5\end{array}$ & 6 & 8 \\
\hline Brejo & - & $1971-20$ & 9 & 9 \\
\hline Coroatá & - & - & 10 & 14 \\
\hline Imperatriz & - & - & - & 6 \\
\hline Totais & Aprox. 99 & Aprox. 85 & Aprox. 106 & 114 \\
\hline
\end{tabular}

Fonte: http://www.catholic-hierarchy.org/; NERIS; SEIDL, 2015c.

\section{Uma elite cultural e militante (1920/1940)}

Superado o duro processo de socialização institucional a que se submetiam os futuros presbíteros recrutados na região, a profissionalização sacerdotal abria para esses jovens postulantes um notável leque de oportunidades de investimento exógeno. Em parte, isso se devia ao próprio estado da estrutura social regional, fracamente diferenciada, caracterizada pela forte monopolização de capitais políticos e culturais em torno de um núcleo bem restrito (proprietários de terra, empresários, políticos, profissionais liberais, elites do estado, comerciantes etc.). Nessas condições, em razão da cultura que esses sacerdotes acumulavam, o ingresso no corpo eclesial não apenas garantia prestígio e distinção social para os seus ocupantes e para os núcleos familiares de onde eram originados, como também favorecia a sua aproximação com as frações das classes dominantes e seus interesses materiais e simbólicos. Formados nesse estado particular das relações entre Igreja, sociedade e política, os clérigos ordenados entre as décadas de 1920/40 parecem ter interiorizado essa função de reconquista de posições no espaço do poder local e de reivindicação do status de "elite dirigente" e "autoridade moral" (NERIS, 2012; RIBEIRO, 2003).

Com efeito, além dos postos internos ao universo religioso (vigários, coadjutores, professores de seminários, membros do cabido diocesano), o ingresso na corporação eclesiástica franqueava a esses sacerdotes a possibilidade de se fazerem presentes simultaneamente em diversos 
domínios (educacional, intelectual, político-administrativo, associativo etc.), onde seus engajamentos apresentavam múltiplas modalidades. Constantino Trancoso Vieira (nascido em 1901 e ordenado em 1925), por exemplo, pouco tempo depois de assumir a paróquia de Pastos Bons de 1930, elegeuse suplente do Senador Clodomir Cardoso (RAPOSO, s/d; Jornal do Maranhão, 16 fev. 1964, p. 1). Astolfo Serra (1900-1978), ordenado em 1925 e filiado à Aliança Liberal, ocupou por um breve período a posição de Interventor do Maranhão em 1931 (ABREU et. al, 2001; CALDEIRA, 1981). Clodomir Brandt (nascido em 1917 e ordenado em 1943), por seu turno, também constitui outro exemplo desse processo de mobilização de competências eclesiais para inserção destacada na esfera política e das formas múltiplas de mediação que o sacerdócio assumia naquela configuração (BATALHA, 2011; MELO, 2013; NERIS, 2014b).

Por outro lado, além de sacerdotes intervirem recorrentemente em âmbito jornalístico (fosse em jornais políticos, de opinião ou corporativos), onde se concentrava o mais importante das disputas por afirmação intelectual e legitimação de intervenções sociopolíticas, de forma contínua ou ocasional, não é fortuito que alguns deles também tenham se engajado na produção literária e até mesmo na formulação de interpretações sobre a história regional e da instituição ao qual estavam vinculados (MELO, 2013; NERIS, 2012; 2014b). Tratase aqui, sem dúvida, daquela fração do corpo eclesiástico cujo investimento no trabalho intelectual de produção escrita permitiu angariar os dividendos pela sua pretensão de influência tanto dentro quanto fora da Igreja (MICELI, 1988).

Em função da cultura acumulada e pelo próprio exercício do culto - que o autori- zava tanto a reunir a população como também, na condição de celebrante, a falar em nome e no lugar da comunidade local -, o padre se encontrava então em situação privilegiada para o exercício da mediação entre diferentes categorias sociais, sobretudo em meio às comunidades dispersas no interior do estado. Não se estranha, pois, que diversos sacerdotes estivessem em condições de mobilizar competências de tipo eclesial (técnicas de fala, redação, manipulação da assembleia), de resto, comuns a outras categorias profissionais como advogados e jornalistas, para entrar com sucesso no jogo propriamente político, integrar-se a instâncias legitimadas de consagração e reprodução cultural (Ensino Superior, Academia Maranhense de Letras, Instituto Histórico e Geográfico do Maranhão, entre outros) e nas disputas pelo controle da vida intelectual e da produção de saberes legitimados socialmente entre os grupos dirigentes locais (MELO, 2013; NERIS, 2014b; NUNES, 2000).

\section{A gestação de uma nova configuração eclesiástica}

Algumas modificações nas condições sociais e institucionais de produção de vocações e de exercício do sacerdócio permitem apoiar a tese do surgimento de uma nova configuração eclesiástica no Maranhão, a partir de meados do século passado. Cabe esclarecer que emprego o termo configuração aqui para designar essa emergência de novos estilos sacerdotais e modalidades de militância institucional que, sem modificar a arquitetura global da Igreja, favoreceram a subversão das rotinas, a difusão de posições críticas e a adoção de estratégias inéditas (LAGROYE, 2006). Isto posto, para caracterizar essa nova configu- 
ração pode-se começar pela já mencionada crise de recrutamento e a diminuição drástica da atratividade pela carreira eclesiástica desde, pelo menos, a década de 1940. Paralelamente, no entanto, também entrou em curso um processo de transformação no sistema de recrutamento e no perfil dos novos sacerdotes, o que se pode notar, inicialmente, pelo incremento regional da quantidade de vocações adultas ou tardias. Habitualmente, definem-se como vocações adultas aquelas que não resultam de uma passagem imediata dos estudos primários para o seminário, o que se expressaria por um ingresso mais tardio. Assim, enquanto no estrato geracional dos anos 1920-1930 as faixas etárias de ordenação se concentravam majoritariamente entre 23 e 25 anos, a partir da década de 1940 o que se observa é uma nítida elevação das faixas etárias de aquisição do estado presbiteral. Entre os padres ordenados nesse recorte, e a respeito dos quais foi possível identificar a idade de ordenação (ao todo, 20), essa tendência se verifica pelo fato de que 14 agentes foram ordenados dentro da faixa etária de 26-36 anos.

Quadro III - Idades de ordenação de sacerdotes a partir da década de 1940.

\begin{tabular}{|l|l|l|l|l|l|}
\hline Qtd. & Padre & Localidade de Origem & Nasc. & Ord. & Idade \\
\hline 1 & Alteredo Soeiro Mesquita & Codó & 1907 & 1943 & 36 \\
\hline 2 & João Batista Costa & São Vicente Ferrer & 1913 & 1943 & 30 \\
\hline 3 & Clodomir Brandt & Picos/Colinas & 1917 & 1944 & 27 \\
\hline 4 & Julio de Freitas Costa & Buriti & 1918 & 1945 & 27 \\
\hline 5 & Walter de Castro Abreu & Pinheiro & 1922 & 1945 & 23 \\
\hline 6 & José Albino Campos & São Vicente Ferrer & 1922 & 1947 & 25 \\
\hline 7 & José de Ribamar Carvalho & Codó & 1923 & 1947 & 24 \\
\hline 8 & Benedito Ewerton Costa & Codó & 1924 & 1948 & 24 \\
\hline 9 & Eider Furtado da Silva & Barro Vermelho & 1917 & 1948 & 31 \\
\hline 10 & Leonel Carvalho & São Luís & 1927 & 1950 & 23 \\
\hline 11 & Oton Salazar & St Rita Codó & 1922 & 1950 & 28 \\
\hline 12 & José de Jesus Travassos Furtado & Viana & 1925 & 1952 & 27 \\
\hline 13 & Wilson Nunes Cordeiro & Matinha & 1922 & 1952 & 30 \\
\hline 14 & Benedito Chaves de Lima & Buriti & 1926 & 1953 & 27 \\
\hline 15 & Manuel Prestes de Lima & Brejo dos Anapurus & 1929 & 1953 & 24 \\
\hline 16 & Heitor Piedade Filho & São Luís & 1928 & 1954 & 26 \\
\hline 17 & Flávio de Sousa Barros & Vitória do Mearim & 1928 & 1954 & 26 \\
\hline 18 & Helio Maranhão & Barra do Corda & 1930 & 1956 & 26 \\
\hline 19 & Sidney Castelo Branco Furtado & Matinha & 1925 & 1957 & 32 \\
\hline 20 & João Miguel Mohana & Bacabal & 1925 & 1960 & 35 \\
\hline
\end{tabular}

Fonte: Livro de matrícula do Clero, s/d. 
Além disso, ocorreu uma nítida intensificação da circulação internacional dentro do estrato geracional mais jovem do corpo clerical local, beneficiado como foi pelo estreitamento de vínculos da Igreja maranhense com centros de formação religiosa e intelectual em nível internacional. É importante mencionar, nesse sentido, que entre as soluções encontradas pelo arcebispo Dom José de Medeiros Delgado (1951-1963) e seu auxiliar, Dom Antonio Fragoso (19571963), para a situação de crise de recrutamento encontrava-se a solicitação de auxílio a dioceses e congregações estrangeiras. Assim, enquanto se aprofundava o processo de imigração de religiosos para o Maranhão constituindo um universo clerical dividido e majoritariamente composto por estrangeiros (NERIS, 2014b), incrementou-se, por outro lado, a circulação de agentes religiosos em sentido inverso, ou seja, daqueles sacerdotes nascidos na região que começaram a obter estágios de curta ou média duração em centros de reflexão localizados fora do Brasil, por meio dos quais adquiriam recursos culturais valorizados dentro da Igreja. Pode-se citar alguns casos desse tipo de trânsito: a começar pelo caso de José de Ribamar Carvalho que, anos depois de sua ordenação (1947) foi enviado para fazer cursos de Pedagogia e Psicologia na França e na Itália entre 1959 e 1960, tendo ainda passagens por cursos de Administração e Supervisão Escolar (Washington/EUA) e em Administração Universitária em Houston (Texas/1972) (FARIA; MONTENEGRO, 2005). Enquanto Sidney Castelo Branco foi encaminhado para a Nova Escócia (costa atlântica do Ca- nadá) com o "objetivo de estudar os sistemas cooperativos na Universidade São Francisco Xavier de Antagonish" (LAVOIE; SOUSA, 2013, p. 53, tradução nossa), o Padre Bonfim seguiu em setembro de 1957 para fazer cursos de Sociologia na Sorbonne e no Instituto Católico de Paris (PACHECO, 1969). Manuel de Jesus Soares e Luís Mario Lula, por seu turno, foram enviados também para o Canadá, em um período no qual trocas eclesiásticas eram correntes entre diversos países e que essa nação se tornava uma destinação particularmente popular junto aos brasilei$\operatorname{ros}^{7}$ (LAVOIE; SOUSA, 2013). 0 sacerdote Hélio Maranhão também foi “[...] presenteado com um curso de teologia em Roma, onde fez bacharelado em teologia pela Universidade Gregoriana de Roma”, orgulhando-se por ter sido "[...] o primeiro padre mandado a Roma para estudar teologia” (NETO, 2007).

Outra dimensão fundamental desse processo de reconfiguração institucional se vinculou à evolução social da demanda religiosa no recorte em pauta, o que requer algumas considerações. A princípio, o que entra aqui em questão não é somente a problemática da recomposição nas estratégias de presença territorial da Igreja local por meio da segmentação das unidades eclesiásticas existentes, como já tivemos a oportunidade de indicar, mas principalmente a adoção de iniciativas pastorais direcionadas a públicos cada vez mais heterogêneos com finalidades religiosas. $\mathrm{Na}$ realidade, a gênese dessas novas frentes de investimento poderia ser remontada à ampliação da presença de organismos confessionais de abrangência internacional,

7. Vale ressaltar que o início da cooperação da Igreja local com dioceses situadas no Canadá teve início quando estas começaram a enviar missionários das Igrejas de Nicolet, Saint Hyacinte (São Jacinto) e Sherbrooke para a Prelazia de Pinheiro (a esse respeito, ver: NERIS, 2014b) 
nacional ou local na região maranhense, notadamente a partir da década de 1930, os quais apresentavam uma multiplicidade de princípios de classificação e se constituíram em veículos privilegiados para a ampliação da presença católica em meio à sociedade política. Tratava-se de movimentos que poderiam diferenciar-se conforme o sexo dos aderentes Pia União das Filhas de Maria (1913), o Núcleo Noelista São Luís Reis de França (1934), União dos Moços Católicos (1924), Ação Católica (1936); por assumir caráter mais abertamente religioso e/ou caritativo o Apostolado da Oração (1880); por ser voltado para categorias socioprofissionais; ou até mesmo por servir como autênticos grupos de pressão e defesa de interesses religiosos junto às instâncias convencionais da política a Liga Eleitoral Católica (1933) (PACHECO, 1969). Apesar de esses movimentos confessionais estarem predominantemente voltados para as elites e concentrados na capital do estado, ao acompanharmos sua evolução de conjunto (NERIS, 2014b), pudemos constatar que diversos deles constituíram detonadores locais para um tipo de engajamento religioso que passava pela mediação do social.

Para o que nos interessa mais diretamente, no entanto, mais decisivas foram as iniciativas promovidas pelo Arcebispo Dom José de Medeiros Delgado (19511963) que, inspirado pelos preceitos do Humanismo Integral de Jacques Maritain, deu início a um programa de intervenção que poderia muito bem ser definido pelo seu caráter multissetorial, já que se traduziu concretamente pela criação de diversas ações articuladas, entre as quais: a ampliação do número de faculdades e a fundação da Universidade Católica do Maranhão na capital do estado (MEIRELLES, 1994; FARIA; MONTENEGRO, 2005; NERIS, 2012); a promoção da Ação Católica Especializada em seus diversos setores, conforme o modelo belga e francês (PACHECO, 1969); a implantação do Movimento Educacional de Base (MEB), cuja atuação foi iniciada na região a partir de 1961 (RAPOSO, 1981); no âmbito comunicacional, destaca-se a criação da Rádio Educadora Rural Ltda. (REMAR), cuja concessão como emissora foi adquirida em 1962; a criação do Departamento Universitário de Rádio, Imprensa e Livro (DURIL) para cuidar da imprensa diocesana; a criação de um ambicioso projeto de intervenção econômica denominado de Ruralismo, o qual combinava uma série diversa de atividades, tais como a criação da Cooperativa Banco Rural do Maranhão, o Movimento Intermunicipal Rural Arquidiocesano (MIRA) e a realização de experiências-piloto de reforma agrária (ALMEIDA, 1981; RAPOSO, 1981; COSTA, 1994; LUNA, 1984); a adoção das experiências das Capelas Rurais, como estratégia de descentralização das vastas paróquias do interior e auxílio no trabalho pastoral (ADRIANCE, 1996) etc. Sem que seja possivel analisar aqui com maior detalhe esses investimentos (NERIS, 2014b), o que importa reter da multiplicação dessas iniciativas, inicialmente, é que elas não representaram exatamente uma diminuição dos investimentos dirigidos às elites, mas uma maior diferenciação dos destinatários dos investimentos religiosos no espaço regional, com o incremento de empreendimentos institucionalizados direcionados para frações do laicato (camponeses, operários, moradores de periferia) portadoras de demandas religiosos inéditas.

Embora diversas dessas novas medidas institucionais tenham sofrido nítida retração desde o final da década de 1960, o fato é que a influência de alguns setores dentro da Igreja sobre essas novas frações foi se inten- 
sificando ainda mais nos decênios seguintes, quer através do importante desenvolvimento das Comunidades Eclesiais de Base (CEB's) e sua crescente politização no espaço rural maranhense, quer por meio da criação e/ou instalação de uma série de ministérios extraparoquiais e organismos militantes criados pela Igreja ou com vínculos com ela (CEBs, Comissão Pastoral da Terra, Federação de Assistência Social e Educacional, Conselho Indigenista Missionário, Movimento de Quebradeiras de Coco, Sindicatos Rurais, etc.) conformando uma rede organizacional que se beneficiava da forte capilaridade social e política da instituição eclesiástica na região (NERIS, 2014b; MACHAD0, 2012; PEREIRA, 2011). Vale dizer que diversos desses organismos se beneficiavam do estabelecimento de convênios com agências nacionais e internacionais de financiamento de projetos sociais, tais como a Cáritas e a Misereor, em um período no qual a Igreja brasileira se tornara, provavelmente, a maior beneficiária da filantropia e da canalização de recursos promovidos pelas redes transnacionais (DELLA CAVA, 2003). Além disso, cabe ressaltar que muito embora algumas dessas organizações não exibissem características nominalmente confessionais, chegando mesmo a haver diversas zonas de fricção, divergências e tensões envolvendo suas lideranças, elas conformaram em conjunto um espaço de engajamento com fronteiras relativamente fluídas, favorecendo a multiposicionalidade dos agentes, as situações de multiengajamento e o trânsito de lógicas e registros, modalidades de interpretação e repertórios de mobilização em vários sentidos. Aliás, caberia ainda aqui a ressalva feita por Johanna Siméant (2009, p. 101), para outro contexto, quando alertava que se o caráter não confessional de um organismo não diz nada acerca dos investimentos religiosos de que ele pode ser objeto, da mesma forma “[...] seria ilusório presumir que as obras confessionais permitiriam usos unicamente religiosos aos seus membros".

Independentemente disso, no entanto, o que nos interessa assinalar é que essa crescente aproximação pastoral da Igreja com os grupos de leigos mais afastados de seus investimentos tradicionais pouco a pouco promoveu modificações importantes no interior da confıguração institucional que vale a pena destacar: primeiramente, é preciso considerar que esse apelo ao laicato foi se tornando indispensável tanto pela carência de efetivos religiosos, quanto pelo fato de que esse recurso representava, até certo ponto, uma tentativa de adequação às novas tendências em curso dentro do espaço católico nacional ou internacional. A questão é que passa a entrar em curso aqui uma nítida diminuição da dissimetria entre leigos e religiosos, resultante do novo lugar assumido por aqueles no seio da Igreja local e para o desenvolvimento de novas iniciativas pastorais. Quer dizer, na medida em que diferentes categorias de leigos passaram a ser encarregadas pela condução de organismos e iniciativas pastorais renovadas, deu-se tanto a redefinição na estrutura objetiva das relações de autoridade propriamente religiosa dentro da configuração institucional católica (padres, religiosos, episcopado, laicato), quanto a complexificação do trabalho de gestão dos bens de salvação (NERIS, 2014b).

Por outro lado, essa aproximação criou também condições para que religiosos se tornassem mais sensíveis aos apelos, problemas e demandas do laicato, sobretudo das categorias mais politizadas, suscitando a incorporação de novas categorias de análise e exigência do ofício religioso. Porém, a complexifıcação da rede organizacional 
gravitando em torno da Igreja não apenas erigiu uma estrutura com postos e atividades mais atrativos às expectativas de religiosos dispondo de habitus mais distanciados em relação à instituição - com destaque aos religiosos de origem estrangeira que ocuparam posições decisivas no processo de politização do engajamento religioso regionalmente (NERIS; SEIDL, 2015c) -, como também fomentou a criação de canais de sociabilidade militante, ampliando os trânsitos e cruzamento de lógicas religiosas e políticas em vários sentidos (MACHAD0, 2012). Em uma conjuntura de intensifıcação dos conflitos e de emergência de diversas mobilizações no campo e na cidade (CARNEIRO, 2013; BORGES, 2008), bastaria dizer que essa rede exerceu um papel de suma importância tanto para a constituição de lideranças “com perfil distinto das 'elites' estabelecidas social e politicamente” (REIS, 2014, p. 359), quanto para a politização de segmentos sociais diversos no Maranhão, sobretudo aqueles mais distantes do universo político convencional, e cujas condições de mobilização seriam improváveis sem esse tipo de apoio (NERIS, 2014b).

Nesse quadro, no que concerne ao subgrupo mais jovem de presbíteros brasileiros ordenados em meados do século XX, enquanto alguns deles se notabilizaram pelo investimento em instâncias e esferas tradicionalmente vinculadas às elites, não muito diferente do que haviam feito os seus antecessores (NERIS, 2012), outros puderam desbravar vias heterogêneas de politização por baixo, enquanto descobriam formas renovadas de conciliação entre a sua origem social humilde, as condições objetivas das paróquias pobres do interior em que se encontravam e as novas perspectivas teológicas em curso nos meios eclesiais na atmosfera pré e pós-conciliar (NERIS, 2014b). Entre outros aspectos, a trajetória analisada a seguir pode ser tomada então como representativa desta modalidade de politização ligada a uma trajetória social ascendente.

\section{Conversão e reconversão de um outsider}

Entre as diversas carreiras religiosas marcadas pelo engajamento em causas sociais no Maranhão (NERIS, 2014b), selecionei o caso de Luís Mario Lula tanto pelo fato de que seu ingresso no corpo eclesial transcorreu precisamente no período de gestação dessa nova configuração institucional, quanto pela sua representatividade no tocante às formas de reconversão de disposições religiosas em posições sociais e culturais inovadoras na região. Além disso, sua biografia (LAVOYE; SOUSA, 2013) constitui um instrumento profícuo para tentarmos captar, na escala de um indivíduo, os sentimentos ambivalentes que afetam a esses agentes submetidos a pressões de mundos sociais diferentes (ELIAS, 1995), a reorientações de trajetória e a uma recomposição do universo dos possíveis que está no princípio da constituição de habitus clivados, geradores de toda sorte de contradições e tensões (BOURDIEU, 2001).

Filho de um comerciante que veio do Piauí para o interior do Maranhão em 1926 e de uma dona de casa, contando com avós comerciantes em ambos os ramos familiares, Luís Mario Lula ${ }^{8}$ nasceu em 1935, em Araioses, sendo o $12^{\circ}$ filho de uma linha-

8. Nessa reconstituição do itinerário de Luís Mario Lula recorremos principalmente à biografia de LAVOYE; SOUSA, 2013, intercalando a exposição com as falas do biografado, em itálico. 
gem de 19 crianças vivas entre vinte gestações. Acompanhando desde cedo os vários negócios que seu pai abriu para garantir o sustento da família (loja de roupas, loja de tecidos, depois uma loja de variedades, um bar contíguo à residência familiar, um hotel etc.), lembra que a infância era marcada por esse ambiente de encontros entre jovens e adultos, de discussões de temas e socialização no sentido largo do termo. E isto poderia ser atribuído, em grande medida, ao fato de que seu pai sempre foi engajado na comunidade, chegando a tornar-se Secretário do Conselho Municipal. Quando estava concluindo o primário e se preparava para os exames de admissão no ensino secundário, no entanto, a falência dos negócios paternos demarcou o início de uma fase difícil para a família de Lula. A partir de então, suas origens sociais já não destoavam dos demais candidatos ao sacerdócio desse mesmo período, cuja passagem pelo seminário representava uma das alternativas mais palpáveis para ascensão social.

Embora a Igreja constituísse um dos principais pontos de referência em sua comunidade, ao contrário da maioria de seus contemporâneos, quando da escolha pelo ingresso no seminário diocesano, os pais de Lula não mantinham boas relações com o pároco local. Não havia muito tempo, seu pai havia sido expulso da Igreja por conta de seu espírito "subversivo e comunista”, esclarece. Embora nessas condições os motivos que o levaram a optar pelo sacerdócio se revelem opacos em sua avaliação retrospectiva, pode-se dizer que o primeiro grande recurso utilizado em prol de seu ingresso no seminário foi a intervenção dessas tias paternas, devotas, cujo apoio financeiro e logístico se mostraria determinante tanto no ingresso, quanto em outros momentos de seu processo de socialização institucional. Com 13 anos, Lula fez, então, sua primeira viagem de avião com destinação ao afamado Seminário Santo Antônio, localizado na capital do estado do Maranhão. Semelhante a diversos outros de sua geração, porém, a experiência de Lula no seminário diocesano, sob a direção dos Lazaristas, ilustra com clareza as difıculdades desses seminaristas vindos do interior para adequar-se aos mecanismos de seleção religiosa, progressivamente ativados sob a ótica da escola, ao passo em que descobriam um novo mundo. É que diferentemente da primeira seleção na paróquia de origem, quando o pároco atentava basicamente para princípios ético-religiosos como demarcadores da vocação, no seminário esses critérios de competência religiosa deveriam combinar-se obrigatoriamente com "boas notas" e "sucesso escolar".

A formação dos seminaristas do Seminário Menor e Seminário Maior, a cargo dos padres Lazaristas, mudava totalmente a perspectiva dos aprendizados que tinha feito até então. No internato, toda a formação repousava sobre dois eixos: o acadêmico e a espiritualidade. Durante todo meu percurso pelo Seminário Menor, tive a chance de viver com professores que tinham a capacidade de transmitir não somente as matérias, como também nos inculcavam o desejo de conhecê-las. Vindo de uma família pobre, o custo de meus estudos eram pagos pela Associação São José que pagou enquanto obtive sucesso sobre o plano acadêmico. Levando em conta todas as minhas lacunas acadêmicas, devido às numerosas mudanças de minha família $\mathrm{e}$ também a outras razões, sem dúvida, eu fracassei um ano, o que pôs fim à subvenção que recebia e colocou em perigo minha permanência no seminário. Desde então, o conselho dos padres lazaristas se interrogou so- 
bre a pertinência de me manter como estudante. A maioria dos membros do conselho decidiu me expulsar, invocando minha falta de vocação. Felizmente, um único padre permaneceu confiante em minhas capacidades e solicitou ao resto do conselho que me dessem uma chance. Enquanto repetidor, a Associação não tinha mais que respeitar seus compromissos financeiros em relação à instituição. Por outro lado, minhas tias paternas que trabalhavam nos Correios se dispuseram a pagar para mim, o que influenciou favoravelmente a comunidade lazarista e me permitiu terminar meu último ano no Seminário Menor. Esse foi para mim o momento de uma forte pressão psicológica e moral, exposto como estava a uma imagem negativa de mim mesmo. A falta de confiança, o olhar dos outros colegas, a atitude dos padres comigo, criaram um sentimento de obrigação de brilhar ou de deixar o seminário. Dom José de Medeiros Delgado, arcebispo de São Luís, não sei por quais razões, decidiu, doravante, enviar-me, em 1955, para o Seminário Maior de João Pessoa, no estado da Paraíba, para fazer meus estudos de filosofia. Esse foi meu primeiro exílio e igualmente, minha salvação, por foi lá que eu retomei confiança em mim (LAVOYE; SOUSA, 2013, p. 48-49, tradução nossa).

Enviado em 1955 para o Seminário de João Pessoa, ao curso dos quatro anos e meio em que permaneceu nessa instituição, seus resultados escolares e sua autoestima foram se modificando sensivelmente. Mais tarde, Dom Delgado, encorajado pelos resultados inesperados, decidiu que Lula deveria compor aquela fração dos sacerdotes locais selecionados para prosseguir sua formação no exterior (teologia no Canadá). De maneira geral, os agentes que tinham esse tipo de passagem em seus percursos sacerdotais gozavam de certa proximidade com os círculos eclesiásticos arquidiocesanos.

Ordenado em 1961, retornou ao Brasil em setembro do mesmo ano a fim de acompanhar o bispo em uma de suas visitas a cavalo, no interior da Arquidiocese. Animado pelas experiências acumuladas no Canadá e esperando atuar na comunidade como o seu pai havia feito, foi com surpresa e até mesmo com certa indignação que esse sacerdote teve de aprender a lidar com os monsenhores das paróquias para as quais foi designado - é que nesse período, como esclarece, quase todas as paróquias eram dirigidas por monsenhores ${ }^{9}$ que se comportavam como os senhores do domínio. Primeiro na cidade de Morros, onde monsenhor Carlos Bacelar exigia que ele apresentasse toda semana um programa de suas ações, ponto por ponto, sendo que vários deles eram vetados, uma vez que o Cura desejava limitar [suas] atividades às pessoas idosas e que o jovem sacerdote se tornasse um simples administrador de sacramentos. 0 entusiasmo de Mario Lula era,

9. Segundo o próprio Luís Mario Lula, Monsenhor era o padre que se atribuía uma superioridade altiva (arrogante) em suas relações com a comunidade. "A hierarquia era constituída assim: o bispo ou arcebispo à frente da diocese; o Monsenhor, auxiliar de bispo; Cônego, cura que era recompensado por sua contribuição particular à Igreja; Cura, padre responsável de uma paróquia; Vigário, padre subalterno ao Cura" (LAVOIE; SOUSA, 2013, p. 69). É importante ressalvar que, embora Luís Mário Lula percebesse assim o papel do Monsenhor, este não faz parte da hierarquia eclesiástica, sendo apenas um título honorífico conferido pelo papa, a pedido do bispo. 
no entanto, fazer progredir a comunidade em direção a uma prática cristã mais dinâmica e aberta sobre a coletividade. Em diversas passagens de sua biografia, relativas a esse período de inserção inicial, não apenas vem à tona a percepção de que o funcionamento da instituição mostravase inadequado para as novas exigências de engajamento, como também se exibe um inabitual senso de oportunidade para implementar ações sacerdotais renovadas quando o contexto fosse julgado oportuno, como segue.

Após cinco meses de frustrações e de desilusões, Lula fez saber então ao arcebispo que tinha um "caso de consciência"10, sendo deslocado em 1962 para outro município, de Pedreiras. Cada localidade, no entanto, representava um novo desafio, como seus colegas padres o fizeram saber, em um daqueles encontros ocasionais onde era possivel conversar, bater-papo sobre nomeações e as reputações de paróquias ou dos seus Curas. Foi precisamente por influência destes colegas de geração que ele resolveu adotar medidas táticas na sua relação com esses monsenhores que, como os avaliava, tinham tido a mesma formação e tinham sido feitos nos mesmos moldes. Como antes, na nova paróquia para o qual foi deslocado, Lula tinha que apresentar relatórios semanais sobre as suas ações para o Monsenhor Gerson Nunes Freire [irmão mais velho do Deputado Federal Osvaldo da Costa Nunes Freire, o qual viria ainda a se tornar Governador do Maranhão entre 1975-1979], porém notou que esse velho sacerdote atribuía mais tempo à administração material da paróquia que ao conjunto da pastoral. Com discrição, o jovem sacerdote foi incitando esse Monsenhor a realizar seus sonhos de administrador mais livremente, à medida em que se comprometia apresentar um balanço semanal das atividades pastorais. Adotando estratégias eficazes para o relaxamento do controle exercido por esse representante do clero dominante na Igreja local, Lula finalmente adquiriu maior liberdade de ação, podendo finalmente ir ao encontro daquelas demandas religiosas que não possuíam condições de serem exprimidas até então na Igreja. Dessa tentativa de aproximação com outros universos sociais resultou diversos efeitos de homologia entre as posições desses padres e outras categorias do laicato, os quais favoreciam a crescente heteronomização da instituição eclesial (NERIS, 2014b).

Ao se comparar a trajetória de Luís Mario Lula com a de outros sacerdotes com perfil de engajamento semelhante, o que se constata é que as tentativas desses jovens clérigos de implementar uma nova cultura religiosa, de que se sentiam portadores, tanto suscitou a adoção de estratégias inéditas que se mostravam contrárias às rotinas e normas de conduta instituídas, quanto exigiu a habilidade de jogar dentro dos limites permitidos pelas relações de força na Igreja local, seja conduzindo lutas mais subterrâneas, seja evitando levar demasiado adiante conflitos, ou dispondose a combates abertos somente quando as conjunturas se mostrassem favoráveis. Em

10. Tratou-se de um estratagema para mudança de paróquia pois, na medida em que recorria a essa expressão, o sacerdote deixava entender que "tinha relações íntimas com uma mulher”, o que geralmente fazia com que um bispo providenciasse uma modificação de posto (LAVOIE; SOUSA, 2013, p. 68-69). 
boa medida, suas disposições eram análogas às dos padres preparados para a crise, de que falava Charles Suaud (1978, p. 182187), noutro contexto, os quais eram dotados de habitus mais maleáveis suscetíveis de colocar em ação tanto práticas sacerdotais tradicionais, que eles desaprovavam ou se opunham, quanto acionar estratégias de luta realistas, quase clandestinas, para impor sobre um terreno desfavorável as disposições inovadoras que haviam incorporado. É justamente esse senso tático que transparece quando Lula avalia o contexto de relativa emancipação da tutela institucional que acabava de conseguir em Pedreiras, como segue:

Era para mim um novo desafio e uma nova ocasião para provar meu engajamento junto aos mais pobres. Eu tinha o desejo de entrar em contato com as pessoas e as situações que exigiriam de mim maior implicação. Eu desejava fazer mais do que a simples administração de sacramentos. Determe nessa tarefa, unicamente, teria significado para mim a banalização de meus ideais e uma vida de mediocridade. Não era para isso que havia sido preparado. Todavia, a hierarquia religiosa me obrigava a usar de tato e paciência (LAVOYE; SOUSA, 2013, p. 48-49, tradução nossa).

Data desse mesmo período o início de sua aproximação dos problemas das mulheres prostituídas na localidade de Pedreiras. Em uma oportunidade, quando de seu convite para animar três dias de encontros do Sindicato dos Estivadores local (situado nas proximidades de um bairro de prostituição), ele foi interpelado por uma mulher que desejava saber por que ele também não fazia uma reunião com elas, com as prostitutas. Foi com embaraço que afırmou que bastaria ela reunir um grupo, o que, para sua surpresa, foi providenciado com bastante rapidez. Na data marcada, coordenou um encontro no mesmo Sindicato reunindo 86 mulheres provenientes de diversas casas locais, sem saber no final das contas o que fazer ou até mesmo o que propor. Decidiu então que o mais conveniente seria indagá-las a respeito do que esperavam que ele fizesse. Entre várias proposições, um consenso se constituiu: aprender a ler e a escrever e também aprender um ofício. Seu primeiro engajamento nessa causa foi então com a disposição de um curso de alfabetização. Contando com o apoio de simpatizantes da causa, e tendo à sua disposição as dependências do Sindicato, começou a oferecer então um curso de alfabetização para prostituídas. Em seguida, contando também com a colaboração do prefeito, obteve máquinas de costura, com o que pôde dar início a mais uma atividade. Paralelamente, incentivava as mulheres a reivindicarem seus direitos, não sem causar certo descontentamento entre os proprietários de casas de prostituição na região (LAVOYE; SOUSA, 2013, p. 96, tradução nossa).

Nessa nova aventura, sentia-se fora de sua zona de conforto, porém, feliz e entusiasmado. Mais do que isso, sentia que essa era a oportunidade para cumprir uma promessa que havia feito a si, quando de uma visita a uma tia materna em estado decadente e agonizante e que havia se lançado na prostituição logo após o suicídio do marido.

A data escolhida para início das novas atividades na paróquia foi o dia 27 de maio de 1963, que lhe parecia mais adequado para recordar para sempre [sua] aliança com o mundo da exclusão, nessa longa marcha para tornar mais humanas as rea- 
lidades dessas mulheres ostracizadas. Em janeiro de 1964, ele participou da fundação do Centro de Recuperação Santa Maria Madalena (CRESMAN). Porém, com a extensão das iniciativas do Centro na localidade, personalidades influentes da cidade começaram a fazer pressão para que fosse dado fim ao trabalho com as prostitutas. A resistência de Lula o tornou então objeto de tentativas de minar sua reputação, e alvo de histórias sórdidas, ao mesmo tempo em que começava a ser tratado como comunista; assim as reuniões do CRESMAN passaram a ser consideradas subversivas. Da mesma forma, proprietários das casas de prostituição passaram a reprovar o comportamento mais autônomo das mulheres que participavam do Centro.

As hostilidades na comunidade repercutiram também no espaço eclesial, e o bispo exigiu que esse engajamento fosse cessado. Para ele, uma tal ação não combinava com minha função, como conta. Foi em uma situação de confrontação com o bispo que Lula deu-se conta então da homologia de sua posição na Igreja com aquela das mulheres prostituídas. É nesse sentido que vale a pena transcrever o trecho abaixo pelo seu potencial elucidativo do processo de politização que está em pauta:

Eu comecei a compreender que quando nos engajamos junto aos excluídos, é necessário esperar ser também marginalizado e criticado como a clientela que se deseja ajudar. É assim um modo de melhor apreender o sofrimento que vivem as pessoas ostracizadas. De certa maneira, as duas partes se sentem igualitárias em seu sofrimento e elas se solidarizam em seu caminho. Eis por que escolhi de recusar o compromisso proposto pelo bispo e que optei de caminhar de mãos dadas com essas mulheres, frequentemente e quase sem- pre vítimas de nossos pré-julgamentos fortemente discriminatórios (LAVOYE; SOUSA, 2013, p. 97, tradução nossa).

Frente à continuidade de seu engajamento junto às mulheres, o bispo tomou como medida a sua designação como Vigário da paróquia de Dom Pedro, o que consequentemente forçou a sua saída da paróquia de Pedreiras. Chegando em Dom Pedro em 1965, porém, suas primeiras palavras e visitas públicas na nova localidade foram realizadas justamente entre as prostitutas da cidade (em um bairro chamado de Molho de Vara). Além disso, contratou uma delas para realizar serviços de limpeza na casa paroquial, bem como para apoiar o trabalho que realizava com um grupo de jovens militantes da Juventude Agrária Católica na região. Como recorda:

Esse episódio da acolhida de uma prostituída no presbitério foi o prelúdio de uma luta encarnada da classe dominante de encontro ao meu ministério. Minha posição face à problemática da prostituição, minha escolha pastoral de ajudar os mais pobres assim como meu modo direto de intervir no conjunto dos problemas da paróquia incomodavam a elite local (LAVOYE; SOUSA, 2013, p. 109, tradução nossa).

Foi então que os notáveis da região decidiram abrir um bar nas proximidades da Igreja, perturbando o desenvolvimento de atividades religiosas. Essa situação criou um impasse político que chegou a envolver o governador, gerando, inclusive, ameaças de morte para Lula. Nessa situação crítica e de risco potencial, Lula decidiu partir para o Canadá, a fim de visitar as redes de amigos que possuía, oportunidade na qual proferiu diversas conferências com o 
propósito de recolher fundos para o CRESMAN. De regresso ao Brasil, esses recursos foram fundamentais para a construção do atual Centro, em 1968. Logo em seguida, foi encarregado pelo Arcebispo de animar a população da diocese de Bacabal em relação à intenção de criação de uma diocese na região. Juntamente com os militantes da Juventude Agrária Cristã (JUAC), visitou diversas localidades, vivenciando diferentes situações de risco de morte. Em seguida, deslocando-se para a cidade de Codó, a convite do Abade Benedito Cutrim e em razão da insegurança em Bacabal, afırma que concentrou sua ação em direção aos bairros pobres que se tornaram paróquias bem organizadas. Gozando de grande liberdade de ação como Vigário (o Cura B. Cutrim, como era conhecido, passava a semana inteira em São Luís onde ele tinha um emprego no Ministério da Educação), Lula sentia que poderia modificar invariavelmente os costumes estabelecidos pelos [seus] predecessores que colaboravam com as dinastias familiares dominantes na cidade.

Novamente sentindo-se marginalizado por conta de seus engajamentos pastorais, acuado pelas diversas ameaças de morte e submetido à vigilância pelas redes de comunicação da ditadura (SNI), decidiu então deixar o país em 1971, justamente em um momento no qual padres amigos foram presos e até mesmo torturados. Considerando todos esses acontecimentos, decidiu então partir para o Canadá. Foi no decurso desse novo período que Lula ficou dividido entre o sacerdócio e a vida laica, na condição de professor. Quando de sua visita ao Brasil em 1975, recontactou uma antiga amiga com a qual veio a se casar em 1977, no Canadá, onde habita até hoje. Em uma das passagens de sua biografia em que avaliava seu próprio itinerário, Lula afırma que seu nome é, talvez, Confluctus, após tudo, posto que em cada paróquia onde eu passei, eu incomodei as normas existentes.

\section{Considerações finais}

Inscrito em um conjunto mais amplo de pesquisas dedicadas a conferir contornos concretos aos processos de institucionalização da Igreja no Brasil e de politização do engajamento religioso (NERIS, 2014b; NERIS; SEIDL, 2015a; 2015b; 2015c; SEIDL, 2014), neste artigo procuramos avançar na objetivação das formas e mecanismos que suscitaram a transgressão dos limites legítimos da ação religiosa católica, no quadro das transformações históricas sucessivas de uma Igreja distante de Roma e das modalidades de adaptação às novas condições de exercício dos papéis religiosos em um território missionário. Tratou-se aqui, portanto, de uma tentativa de apreender tanto as modificações contínuas na arquitetura global desse componente da Igreja, as estratégias territoriais em disputa, quanto oferecer elementos concretos para a avaliação das relações objetivas que uniam esses diferentes elementos e que asseguravam a sua perpetuação e transformação.

Nesse quadro, o avanço na reconstituição dos processos de transformação institucional da Igreja através desse pequeno componente objetivado levou então a identificar uma série de aspectos importantes para tornar inteligível a politização de padres brasileiros em seu contexto de possibilidade. A começar pelo fato de que os modos de exercício religioso no Maranhão, notadamente a partir da década de 1950, afiguravam-se como cada vez mais distintos em relação às lógicas de intervenção do corpo eclesial que caracterizavam o estado imediatamente anterior da 
confıguração eclesiástica, quando havia um maior ajustamento entre a Igreja e os princípios de distribuição de poder vigentes em uma sociedade pouco diferenciada e organizada economicamente em torno da terra, como a maranhense (NERIS; SEIDL, 2015c). Como visto, as transformações nos modos de exercício do ofício religioso na região se conectaram a uma multiplicidade de fatores, tais como: as modificações nas condições de produção e socialização institucional, paralelamente ao aprofundamento da crise de reprodução do clero local; a recomposição nas estratégias de presença territorial da Igreja local, exigindo a mobilização de diferentes agentes (leigos e estrangeiros, notadamente) para a execução de tarefas outrora reservadas exclusivamente aos padres; a intensificação da circulação internacional entre as frações mais jovens do corpo eclesial local, ao passo em que se estreitavam os vínculos da Igreja no Maranhão às redes transnacionais católicas (NERIS; SEIDL, 2015) etc. Em conjunto, todos esses fatores contribuíram para ampliar notavelmente o espectro de inserção sociopolítica de clérigos, legitimando, a um só golpe, a exploração de novas vias de politização religiosa e de conciliação entre disposições sociais, engajamentos e carreiras institucionais. Ou seja, pela via das experiências concretas de clérigos em atividades sobre as quais a hierarquia não tinha pleno controle foi-se gestando uma nova configuração institucional, que tanto contribuiu para desestruturar as cadeias tradicionais de transmissão da autoridade no seio da Igreja local, quanto ampliou o espectro de fidelidades e as modalidades de militância institucional no espaço católico ${ }^{11}$.

Centrando o foco sobre os clérigos seculares recrutados na região maranhense, pudemos delimitar mais claramente uma matriz importante das "carreiras de politização” (AÏT-AOUDIA; BENNANI-CHRAÏBI; CONTAMIN, 2011) ligada a trajetórias de mobilidade social ascendente em uma conjuntura crítica de subversão de rotinas e flutuação dos critérios objetivos de pertencimento. É nesse sentido que a análise da trajetória de Luís Mario Lula mostrou-se rica em elementos para compreender como esses rebentos de camadas empobrecidas

cujo ingresso na instituição exigia um alongado e custoso processo de reconstrução de si para permitir a aculturação a um novo meio social não apenas incorporaram disposições tradicionais, como também desenvolveram uma forte predisposição ao questionamento das normas em vigor, tanto as do mundo social (a sua própria trajetória seria uma prova disso), quanto aquelas do meio em que se encontravam. Em assim sendo, por sua dupla situação de deslocamento espacial e cultural, quer em relação ao meio social de origem, quer no que concerne ao novo espaço de inserção, esses outsiders eram expostos então a diversas sanções negativas (formas de estigmatização, humilhação, sentimentos de descompasso) resultantes da defasagem experimentada entre as disposições incorporadas e as exigências institucionais.

Em suma, posicionados entre a fidelidade ao grupo social de origem, o imperativo de integração ao sacerdócio e as situações

11. Produto de uma tentativa de reajustamento, como esclarece Yann Raison du Cleziou (2011, p. 271), “a fidelidade é um investimento reflexivo na instituição tornado necessário pelo desajustamento entre o habitus e a instituição, a dissonância entre as estruturas mentais e o espaço social”. 
antagonistas as quais se expunham, ao encontrarem investimentos mais gratificantes e adaptados às suas disposições sociais, esses outsiders puderam, a um só golpe, engajar-se em lutas a favor dos mais "pobres”, dos "excluídos” e com isso adquirir um lugar próprio no mundo eclesial (NERIS, 2011), mesmo ao preço doloroso, por vezes insustentável, de ser contrários às normas e condutas instituídas. Neste particular, o caso de Lula também poderia ser tomado como ilustrativo da situação de diversos religiosos que romperam com o estado clerical para prosseguir ou reconverter sua fidelidade religiosa sob outras modalidades, o que constitui uma faceta instigante e ainda pouco explorada da recomposição das formas de militância institucional e das próprias ambivalências, que pode assumir a reconstrução de si e a fé em uma instituição.

\section{Referências}

ABREU, A. A.; BELOCH, I.; LAMARÃO, S. T. N.; LATTMAN-WELTMAN, F. Dicionário históricobiográfico brasileiro pós-30. 2. ed. Rio de Janeiro: FGV, 2001.

ADRIANCE, M. Terra prometida: as comunidades eclesiais de base e os conflitos rurais. São Paulo: Paulinas, 1996.

AÏT-AOUDIA, M.; BENNANI-CHRAÏBI, M.; CONTAMIN, J. G. Indicateurs et vecteurs de la politisation des individus: les vertus heuristiques du croisement des regards. Critique internationale, 1/ 2011 (n. 50), p. 9-9. Disponivel em: http:// www.cairn.info/resume.php?ID_ARTICLE=CRII_050_0009. Acesso em: 10 maio 2012.

ALMEIDA, A. W. B. Autonomia e mobilização política dos camponeses no Maranhão. São Luís: CPT-MA, 1981.

ALVES, M. M. A igreja e a política no Brasil. São Paulo: Brasiliense, 1979.
BATALHA, J. F. Um passeio pela história de Arari. São Luís: Lithograf, 2011.

BEOZZO, J. O. A Igreja entre a Revolução de 1930, o Estado Novo e a Redemocratização. In: FAUSTO, B. (Org.). História Geral da Civilização Brasileira. São Paulo: Difel, v. 11, 1986, p. 271-341.

. Padres conciliares brasileiros no Vaticano II: participação e prosopografia 1959-1965. 2001. 436f. Tese (Doutorado em História) Faculdade de Filosofia, Letras e Ciências Humanas. Universidade de São Paulo, São Paulo, 2001.

BOURDIEU, P. Science de la science et reflexivité: Cours du Collège de France, 2000-2001. Éditions raison d'agir: Le Seuil, 2001.

BRUNEAU, T. C. 0 catolicismo brasileiro em época de transição. São Paulo: Loyola, 1974.

Religião e politização no Brasil. São Paulo: Loyola, 1979.

CALDEIRA, J. R. C. As interventorias estaduais no Maranhão: um estudo sobre as transformações políticas regionais no pós-30. 1981. 332f. Dissertação (Mestrado) - Universidade de Campinas. São Paulo: 1981.

CARNEIRO, M. D. S. Terra, trabalho e poder: conflitos e lutas sociais no Maranhão contemporâneo. São Paulo: Anablume, 2013.

CERIS - Centro de Estatística Religiosa e Investigações Sociais. Anuários Católicos Do Brasil. Disponivel em: http://www.cps.fgv.br/cps/religiao. Acesso em: 21 mar. 2013.

CERIS. Dinâmica populacional e a Igreja Católica no Brasil: 1960-2000. Rio de Janeiro, ano 2, n. 3, out. 2002.

CORADINI, O. L. Os usos das ciências humanas e sociais pelo catolicismo e pelo luteranismo e as relações centro/periferia. Revista Pós Ciências Sociais - Repocs, v. 9, p. 67-99, 2012.

COSTA, W. C. 0 rosto rural da Igreja: A atuação da CPT no Maranhão (1976-1981). 1994. 59f. Monografia (Licenciatura em História) - Universidade Federal do Maranhão. São Luís, 1994. 
DE ROUX, R. La romanización de la Iglesia católica en América Latina: una estrategia de larga duración. Revista Pro-Posições: Campinas, v. 25, n. 1, p. 31-54, 2014.

DELGAD0, D. J. M. Plano de evangelização da arquidiocese de São Luís do Maranhão. Disponível em: Correspondências expedidas pelo DAER, Arquivo da Curia Metropolitana, São Luís, 1962.

DELLA CAVA, R. Religiões transnacionais: Igreja Católica Romana no Brasil e a Igreja Ortodoxa da Rússia. Civitas: Porto Alegre, v. 3, n. 1, p. 149167, 2003.

DOBRY, M. Sociologia das crises políticas: a dinâmica das mobilizações multissetoriais. São Paulo: Editora Unesp, 2014.

ELIAS, N. Mozart, sociologia de um gênio. Rio de Janeiro: Jorge Zahar, 1995.

ESTATÍSTICA do Culto Católico Romano. Serviço de estatística demográfica; moral; política. Províncias eclesiásticas do Brasil, 1950.

ESTATÍSTICA do Culto Católico Romano (IBGE). Série histórica de 1936 a 1983. Disponível em: http://seculoxx.ibge.gov.br/populacionais-sociais -politicas-e-culturais/busca-por-palavra-chave/ associativismo/606-culto-catolico. Acesso em: 19 mar. 2013.

FARIA, R. H. M.; MONTENEGRO, A. (Orgs). Memória de professores: histórias da UFMA e outras histórias. São Luís : UFMA/DEHIS; Brasília: CNPq, 2005.

LAGROYE, J. La vérité dans l'Église catholique: contestations e restauration d'un régime d'autorité. Paris: Belin, 2006.

Appartenir à une institution: catholiques en France aujourd'hui. Paris: Économica 2009.

LAVOYE, A.; SOUSA, F. A. Une fenêtre sur la vie: histoire d'un engagement envers les femmes marginalisées. Quebec: Solidarité Brèsil - Outaouais, 2013.

LIVRO DE MATRÍCULA DO CLERO DIOCESANO, 1882.
LUNA, R. C. M. R. A terra era liberta: um estudo da luta dos posseiros pela terra no vale do Pindaré -Maranhão. São Luís, UFMA/Secretaria Educação do Maranhão, 1984.

MACHAD0, J. L. F. Ação política, missão pastoral e instâncias de inserção: engajamento de clérigos no Maranhão (1970-1980). 2012. 132f. Dissertação (Mestrado em Ciências Sociais) - Universidade Federal do Maranhão, São Luís, 2012.

MARIN, R. Dom Helder Camara, les puissants et les pauvres. Pour une histoire de l'Église des pauvres dans le Nordeste brésilien (1955-1985). Paris: Les Éditions de l'Atelier - Les Éditions Ouvrières, 1995.

MEIRELLES, M. M. História da Arquidiocese de São Luís do Maranhão. São Luís: Universidade do Maranhão/SIOGE, 1977.

MELO, H. F. 0 ofício de sacerdote: mediação cultural, atuação política e produção intelectual de padres no Maranhão. 2013. 190f. Dissertação (Mestrado em Ciências Sociais) - Universidade Federal do Maranhão, São Luís, 2013.

MICELI, S. A elite eclesiástica brasileira. Rio de Janeiro: Bertrand Brasil, 1988.

NERIS, W. Silva. As vias de politização sacerdotal no Maranhão (1950-1990). Tomo (UFS), v. 19, p. 133-184, 2011

Elementos para uma história social da militância católica no Maranhão. In: CARREIR0, G. S.; FERRETI, S. F.; SANTOS, L. A. (Orgs.) Missa, culto e tambor: os espaços da religião no Brasil. São Luís, EDUFMA/FAPEMA, 2012, p. 143-160.

A elite eclesiástica no bispado do Maranhão. São Luís/Jundiaí: Edufma/Paco Editorial, 2014a.

Igreja e Missão: religiosos e ação política no Brasil. 2014. 404f.Tese (Doutorado em Sociologia). Universidade Federal de Sergipe, São Cristóvão, 2014b.

SEIDL, E. Circulação internacional, politização e redefinições do papel religioso. Revista 
Brasileira de História da Educação, v. 15, p. 285315, 2015 a.

SEIDL, E. Redes transnacionais católicas e os Padres Fidei Donun no Maranhão (1960-1980). História Unisinos, v. 19, p. 138-151, 2015b.

SEIDL, E. Uma Igreja distante de Roma: circulação internacional e gerações de missionários no Maranhão. Estudos Históricos (Rio de Janeiro), v. 28, p. 129-149, 2015 c.

NETO, M. S. A saga do poeta que ganhou o mundo e virou Monsenhor. Jornal Pequeno, Ano V, Edição 149, jan. 2007. Disponível em: http://www. guesaerrante.com.br/2007/1/12/Pagina859.htm>. Acesso em: 16 out. 2013.

NUNES, P. M. P. Medicina, poder e produção intelectual. São Luís: EDUFMA. PROIN (CS), 2000.

PACHECO, D. F.C. História Eclesiástica do Maranhão. São Luís: Departamento de Cultura do Estado, 1969.

PELLETIER, D. De la mission au tiers-mondisme: crise ou mutation d'unm modèle d'engagament catholique. Le mouvement social, octobre-decémbre, n. ${ }^{\circ} 177,1996$.

; La crise catholique. Religion, societé, politique en France (1965-1978). Paris: Payot. 2002.

PEREIRA, J. M. Engajamento militante e a "luta pela moradia em São Luís" entre as décadas de 1970 e 1980. 2011. 201 fls. Dissertação (Mestrado em Ciências Sociais) - Universidade Federal do Maranhão, São Luís, 2011.

RAISON DU CLEZIOU, Y. Quand une génération en cache une autre. Politix 4/2011b (n. 96), p. 115138. Disponivel em: http://www.cairn.info/resume.php?ID_ARTICLE=P0X_096_0115. Acesso em: 24 nov. 2012.

Des fidélités paradoxales: recompositions des appartenances et militantisme institutionnel dans une institution en crise. In: LAGROYE, J.; OFFERLÉ, M. Sociologie de l'institution. Paris: Belin, 2010, p. 267-290.
RECONVERSIONS MILITANTES. Textos reunidos por Sylvie Tissot, com Christophe Gaubert, Marie Hélène Lechien. Limoges: Presses Universitaires de Limoges, 2005.

RIBEIRO, E. S. Igreja católica e modernidade no Maranhão. 1889-1922. 2003. 173f. Dissertação (Mestrado em História) - Universidade Federal de Pernambuco, Recife, 2003.

SAINT MARTIN, M. Da reprodução às recomposições das elites: as elites administrativas, econômicas e políticas na França. Tomo, São Cristóvão-SE, n. 13, jul./dez. 2008.

SEIDL, E. A elite eclesiástica no Rio Grande do Sul. 2003. 462f. Tese (Doutorado em Ciência Política) - Universidade Federal do Rio Grande do Sul, Porto Alegre, 2003.

. E. Um discurso afinado: 0 episcopado católico frente à "política" e ao "social”. Horizontes Antropológicos (UFRGS. Impresso), v. 13, p. 145-164, 2007a. Disponivel em: http://www.scielo.br/scielo. php?pid=S0104-71832007000100007\&tscript=sci_arttext. Acesso em: 18 jun. 2015.

E. Circulação internacional de religiosos, formação de quadros católicos e condições de intervenção política. Projeto de Pesquisa, CNPq, mimeo, 2014.

Lógicas Cruzadas: carreiras religiosas e política. Revista Pós Ciências Sociais, v. 6, n. 11, p. 11-27, 2009.

SERBIN, K. P. Diálogos na sombra: bispos e militares, tortura e justiça social na ditadura. São Paulo: Companhia da Letras, 2001.

Padres, celibato e conflito social: uma história da Igreja católica no Brasil. Tradução Laura Teixeira Motta. São Paulo: Companhia das Letras, 2008.

SIMÉANT, J. Socialisation catholique et biens de salut dans quatre ONG humanitaires françaises. Le Mouvement social, maio 2009, p. 101-122. Disponivel em: http://www.cairn.info/revue-le-mouvement-social-2009-2-page-101.htm. Acesso em: 09 maio 2010. 
SUAUD, C. La vocation: convertion et reconvertion des prêts ruraux. Paris: Minuit, 1978.

. As lutas religiosas do ponto de vista de uma sociologia da incorporação. 0 corpo sacerdotal (católico) entre doutrina e inovação. Revista da Faculdade de Letras/Sociologia, Faculdade de Letras da Universidade do Porto. Série I, v. 1(1991). - Anual. - ISSN 0872-3419. Disponível em: http:// ler.letras.up.pt/uploads/ficheiros/7201.pdf. Acesso em: 10 jul. 2010.

\section{Jornais consultados}

Jornal do Maranhão (1958-1968) 
RESUMO

0 texto tem como questão central o problema das mediações concretas por meio das quais certos membros do corpo clerical foram conduzidos a transgredir os limites tradicionais da ação religiosa católica, tendo como referencial de análise uma unidade representada pelo Maranhão a partir da segunda metade do século XX. A partir da exploração das transformações na composição do clero atuante na região, das mutações na configuração eclesiástica e da narrativa biográfica de um sacerdote de origem local, o texto delimita uma matriz importante das reconversões militantes de padres ligada a trajetórias de mobilidade social ascendente em uma conjuntura institucional crítica. A análise contextualizada do trabalho de incorporação e reconversão de disposições desses religiosos permite apreender então as ambivalências, as experiências dolorosas e o longo processo de reconstrução identitária, necessários para que esses agentes adquirissem um lugar próprio no mundo eclesial.

\section{PALAVRAS-CHAVE}

Maranhão. Padres. Reconversões militants. Reconstrução identitária.

\section{ABSTRACT}

The main issue of this article is the actual mediations through which members of the clerical body were led to cross the traditional boundaries of the Catholic action. The analysis focused on the Brazilian State of Maranhão from the second half of the twentieth century on. Based on the study of the changes in the composition of the clergy and in the ecclesiastical structure, as well as on the biographical narrative of a local priest, the work revealed an important array of militant reconversion of priests. Those trajectories were connected to upward social mobility in a critical institutional situation. The context-based analysis of the process of internalization and conversion of social dispositions experienced by those priests brought to light ambivalences, painful experiences, and a long process of identity reconstruction required to the conquering of their own place in the ecclesiastical world.

\section{KEYWORDS}

Maranhão. Priests. Militant reconversion. Identity reconstruction. 
